\title{
A case of Emys orbicularis (L.) feeding on newts from Bulgaria
}

\author{
Vladislav Vergilov', Angel Dyugmedzhiev ${ }^{2}$, Sylvia Georgieva³, Miroslav Slavchev 5
}

(1) [Corresponding author] National Museum of Natural History at the Bulgarian Academy of Sciences, 1 Tsar Osvoboditel Blvd, 1000 Sofia, Bulgaria, vladislav8807@gmail.com $\nabla$; https://orcid.org/0000-0002-7464-2263 [

(2) Institute of Biodiversity and Ecosystem Research, Bulgarian Academy of Sciences, 2 Gagarin Street, 1113 Sofia, Bulgaria

(3) University Specialized Hospital for Active Treatment in Oncology EAD, 6 Plovdivsko Pole Street, 1756 Sofia, Bulgaria, silvia1988georgieva@gmail.com $\sim$; https://orcid.org/0000-0002-1203-6946[ [

(4) angel_diugmedjiev@abv.bg $\backsim$; https://orcid.org/0000-0003-3765-7076[

(5) slmiro@abv.bg 0 ; https://orcid.org/0000-0002-2426-8875 [ك

\begin{abstract}
Different amphibians and amphibian larvae were already observed and described as part of the diet of the European pond turtle. Few studies report body parts from adult newts in the stomach content of Emys orbicularis (Linnaeus, 1758) or newts predated by the same pond turtle species. We observed remains of Triturus dobrogicus (Kiritzescu, 1903) and Trituris ivanbureschi Arntzen \& Wielstra, 2013 eaten by E. orbicularis inside funnel traps, which strongly suggests, that newts are part of the diet, although not typical and often eaten food by this pond turtle.
\end{abstract}

Keywords: feeding, pond turtle, predation, protected area, traps, Triturus

The European pond turtle Emys orbicularis (Linnaeus, 1758) and different species of newts very often live in the same water bodies (Fritz, 2003; Stojanov et al., 2011; Speybroeck et al., 2016). Fritz (2003) summarised and discussed the information about the biology and ecology of E. orbicularis. Fritz (2003), Ottonello et al. (2005) and Stojanov et al. (2011) mentioned "amphibians and their larvae" as part of the diet of the turtle. Kuzmin (1999) reported that the larvae of Ommatotriton vittatus Gray, 1835 were preyed by E. orbicularis. Different amphibians and amphibian larvae have already been observed and described as part of the diet of the European pond turtle (Stojanov et al., 2011; Çiçek \& Ayaz, 2011), but the question of whether $E$. orbicularis feeds on adult newts, because of their toxicity, is interesting. Ducortterd et al. (2020) have already mentioned that E. orbicularis feeds on Bufo bufo (Linnaeus, 1758), a species that is also toxic. Çiçek \& Ayaz (2011) reported body parts of the newts Lissotriton vulgaris (Linnaeus, 1758) and Trituris ivanbureschi Arntzen \& Wielstra, 2013 (as T. karelinii (Strauch, 1870) with small percentage in the stomach content of females of E. orbicularis. Szczerbak \&
Szczerban (1980) also mentioned T. cristatus (Laurenti, 1768) and T. dobrogicus (Kiritzescu, 1903) in the stomach content of E. orbicularis, but do not provide any further information about that statement. Similar information, about the European pond turtle predating on species of Triturus, has been provided by Kuzmin (1999) (for T. cristatus) and Fahrbach \& Gerlach (2018) (for genus Triturus). Again, the authors (Kuzmin, 1999; Fahrbach \& Gerlach, 2018) do not provide any details, supporting these statements.

Our observations took place during field work in April and May 2021 in Northern Bulgaria. While studying the distribution of amphibians and reptiles in the area, we set 30 traps for one night (19:00-9:00 h) in ponds of two localities - Kaikusha Protected site, near Belene Town (N43.596, E25.200 $)$ (Fig. 1A) on 23 April 2021, and near Debovo Village (N43.601 ${ }^{\circ}$, E24.882 ${ }^{\circ}$ (Fig. 1B) on 5 May 2021. We set funnel traps $(25 \times 25 \times 60 \mathrm{~cm})$ in a marshland with more than 80 $\%$ bullrush cover and with open water areas as well. The depth of the water, where the traps had been set, was approximately between 20 and $100 \mathrm{~cm}$. We collected the traps the following morning, when we observed 
Vladislav Vergilov, Angel Dyugmedzhiev, Sylvia Georgieva, Miroslav Slavchev
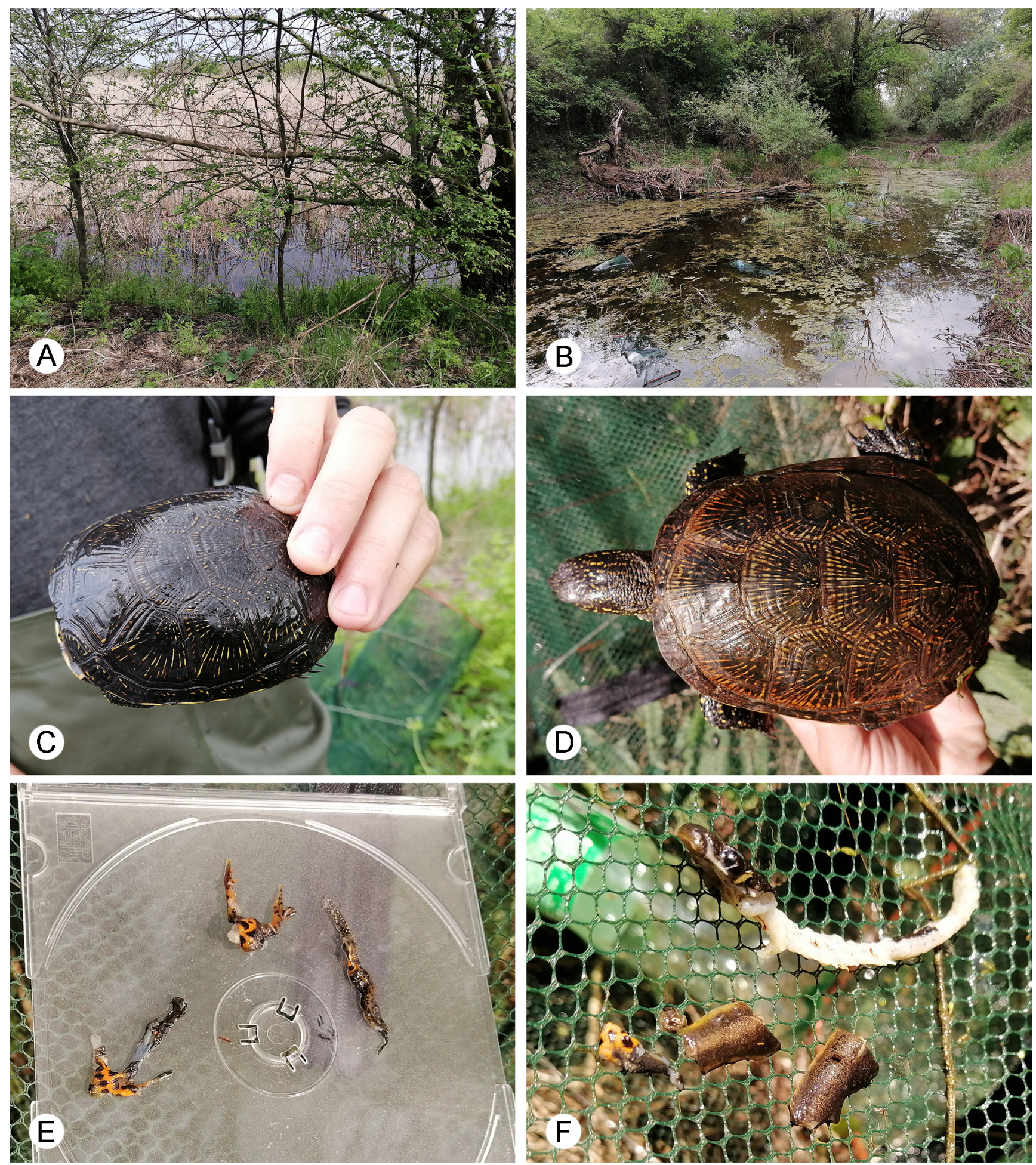

Fig. 1. The newt remains from the E. orbicularis attack in the traps. A - Kaikusha Protected site; B - pond near Debovo Village; $\mathrm{C}-$ E. orbicularis from the trap of Kaikusha Protected site; D - E. orbicularis from the trap of the pond near Debovo Village; E - T. dobrogicus remains from Kaikusha Protected site, F - T. ivanbureschi remains from the pond near Debovo Village.

something unusual. In one of the traps from the Kaikusha Protected site there was the usual huge amount of amphibian larvae (Bombina bombina (Linnaeus, 1758), Pelophylax ridibundus (Pallas, 1771), 
one adult female E. orbicularis (Fig. 1C) and remains of an adult newt. The remains consisted of the forelimbs and skin from the abdomen and the back of the amphibian (Fig 1E). A closer observation revealed that they were from an adult $T$. dobrogicus. Inside the other traps, where more newts were found (all alive and vital), there was no E. orbicularis. A similar observation was made from the second locality, the pond near Debovo Village, with the exception that the remains were of $T$. ivanbureschi. It was the only newt in the trap, but again with another adult female of $E$. orbicularis (Fig. 1D). Almost all of the soft tissue of this individual was eaten, the only parts left uneaten were the head (without the lower jaw), still attached to the vertebral column, parts of the tail and a piece of skin (Fig 1F).

It appears that newts are part of the diet, but not typical and often eaten food item for this pond turtle. After the publications of Szczerbak \& Szczerban (1980), Kuzmin (1999), Fahrbach \& Gerlach (2018) and the results of Çiçek \& Ayaz (2011), we can now conclude that our observation is not due to some stress situation (caused by the traps), but a natural behaviour of individuals of $E$. orbicularis feeding on newts. Moreover, the European pond turtle is an opportunistic species when it comes to feeding (Fritz, 2003; Stojanov et al., 2011; Speybroeck et al., 2016), that would feed on anything that could catch (even carcasses). We could speculate that the traps limited the escape possibilities of the newts, therefore benefiting the successful praying of the individuals of $E$. orbicularis.

\section{Acknowledgements}

We are grateful to Dr Richard Gemel, Dr Boyan Zlatkov, Dr Borislav Naumov and Dr Georgi Popgeorgiev for their valuable advices and guidelines. All fieldwork was carried in accordance with the Ministry of Environment and Water of Bulgaria's Permit No. 861/13.01.2021.

\section{References}

Çiçek K., Ayaz D. 2011 Food composition of the European pond turtle (Emys orbicularis) in Lake Sülüklü (Western Anatolia, Turkey). Journal of Freshwater Ecology 26 (4): 571-578. https://doi.org/10.1080/02705060.2011.580536 [

Ducotterd C., Crovadore J., Lefort F., Guisan A., Ursenbacher S., Rubin J.-F. 2020 The feeding behaviour of the European pond turtle (Emys orbicularis, L. 1758) is not a threat for other endangered species. Global Ecology and Conservation 23: $\mathrm{e} 01133$. https://doi.org/10.1016/j.gecco.2020.e01133 ¿

Fahrbach M., Gerlach U. 2018 Die Gattung Triturus. Chimaira, Frankfurt am Main, 550 pp.

Fritz U. 2003 Die Europäische Sumpfschildkröte. Laurenti, Bielefeld, 224 pp.

Kuzmin S. 1999 The amphibians of the former Soviet Union. Pensoft, Sofia-Moscow, 538 pp.

Ottonello D., Salvidio S., Rosecchi E. 2005 Feeding habits of the European pond terrapin Emys orbicularis in Camargue (Rhône Delta, Southern France). Amphibia-Reptilia 26 (4): 562-565. https://doi.org/10.1163/156853805774806241 〔ك

Speybroeck J., Beukema W., Bok B., Voort J.V.D. 2016 Field guide to the Amphibians and Reptiles of Britain and Europe. Bloomsbury Publishing Plc., London, $432 \mathrm{pp}$.

Stojanov A., Tzankov N., Naumov B. 2011 Die Amphibien und Reptilien Bulgariens. Chimaira, Frankfurt am Main, 588 pp.

Szczerbak, N.N., Szczerban M.I. 1980 Zemnovodnye i Presmykayushchiesya Ukrainskikh Karpat [Amphibians and Reptiles of Ukrainian Carpathians]. Naukova Dumka, Kiev, 266 pp. (In Russian) 